\title{
Kasper Lippert-Rasmussen
}

politica, 39. årg. nr. 4 2007, 368-384

\section{Diskrimination: definition og moral}

Sociale problemer og uligheder kategoriseres ofte som afspejlende diskrimination. Det er imidlertid langt fra klart, hvori præcist diskrimination består, og derfor heller ikke klart, hvorfor diskrimination er uretfærdig. Artiklen behandler disse to spørgsmål. Jeg argumenterer for den forholdsvis ukontroversielle tese, at diskrimination er forskelsbehandling af en bestemt art, men at der er flere forskellige bud med belæg i blandt andet dagligsproget på, hvilken særlig art af forskelsbehandling diskrimination udgør. På baggrund heraf indkredser jeg et begreb om diskrimination, det forekommer relevant at fokusere på i forhold til spørgsmålet om diskriminationens moralske kvaliteter, og viser, at det formentlig næppe kan hævdes med afsæt $i$ alment accepterede moralforestillinger, at alle former for diskrimination er problematiske. Hvis $\mathrm{fx}$ det antages, at diskrimination er moralsk problematisk, (alene) fordi det fremmer mulighedsuligheden i samfundet - en ganske almen anke mod diskrimination - så følger det, at vi ingen grund har til at anse lighedsfremmende diskrimination - hvor sjælden en sådan form end måtte være - for at være moralsk problematisk.

„Diskrimination“ lever en dobbelttilværelse. Udtrykket bruges i en række akademiske discipliner. Inden for jura er diskrimination $\mathrm{fx}$ noget i retning af ulovlig forskelsbehandling af medlemmer af forskellige retsligt beskyttede grupper, der ikke er begrundet i tilstrækkeligt vægtige hensyn. Ifølge den opfattelse er forskelsbehandling, som er begrundet i sådanne hensyn, dermed ikke diskrimination. I sociologien har diskriminationsforståelsen naturligt nok ikke samme fokus på spørgsmålet om legalitet. Anthony Giddens betoner, at selvom fordomme og diskrimination ofte optræder sammen, så forekommer der fordomsfri diskrimination (og diskriminationsfri fordomme). Diskrimination er nemlig simpelthen „(a)ctivities that deny to the members of a particular group resources or rewards which can be obtained by others" (Giddens, 1997: 582). ${ }^{1}$ "Diskrimination" bruges også flittigt i dagligsproget uledsaget af nogen klar opfattelse af, hvori diskrimination består. I mange dagligsproglige sammenhænge betegner „diskrimination“ simpelthen forskelsbehandling, som taleren anser for at være uretfærdig eller umoralsk. Det sker dog, at personer medgiver, at en given form for forskelsbehandling udgør diskrimination, men samtidig fastholder, at den pågældende forskelsbehandling er acceptabel. ${ }^{2}$

Noget forsimplet (og jf. nedenfor måske lidt kynisk) kunne man sige, at der generelt hersker en antagelse om, at diskrimination udgør en særlig alvorlig form for uretfærdighed. Grupper har derfor en politisk interesse i at fremstille deres på forskellige måder ufordelagtige situation, som et resultat af diskrimination mod dem snarere end som en følge af andre årsager. Det kan, i lighed med andre forhold, medføre et vist inflatorisk pres på diskriminationsbegrebet, 
således at stadig flere fænomener beskrives som udtryk for diskrimination, jf. $\mathrm{fx}$ anken om, at rygeforbud på arbejdspladsen er diskrimination mod rygere, og påstanden om, at rabatordninger på billetter til Det Kgl. Teater for personer med en ikke-vestlig etnisk baggrund udgør racediskrimination. ${ }^{3,4}$ Det er dog også klart, at langtfra alle fænomener, der anses for at være uretfærdige eller umoralske, kaldes for diskrimination. Fx er det trods massiv underrepræsentation ualmindeligt at tale om, at unge fra lavindkomstgrupper udsættes for diskrimination i uddannelsessystemet (mere herom nedenfor).

I nærværende artikels første halvdel definerer jeg diskrimination som, groft sagt, forskelsbehandling af forskellige socialt fremtrædende grupper. Den definition har visse implikationer for, hvad begrundelsen for, at diskrimination er moralsk forkert, kan være, og i artiklens anden halvdel diskuterer jeg med udgangspunkt i den foreslåede definition fire udbredte opfattelser af, hvorfor diskrimination er moralsk forkert. Artiklens centrale påstand er, at de egenskaber, der gør noget til diskrimination, formentlig ikke er de egenskaber, der gør det moralsk forkert. Det, at noget udgør diskrimination, er en god indikator på, at det er moralsk forkert, men at det forholder sig således følger ikke med nødvendighed.

\section{Hvad er diskrimination?}

Man kan diskriminere mod eller til fordel for et individ. Man diskriminerer mod (til fordel for) et individ, hvis man behandler individet dårligere (bedre) end andre. I tilfælde hvor man behandler individer forskelligt men ikke behandler nogen dårligere end andre, diskriminerer man mellem dem, uden at man diskriminerer mod nogen af parterne. Fokus i denne artikel ligger på diskrimination mod individer.

To vigtige præciseringer af dette fokus bør nævnes. Det kan være lidt kompliceret at afgøre, hvad det vil sige at behandle nogen dårligere end andre. Det forhold, at der er en beskrivelse, under hvilken nogen behandler to individer på samme måde, indebærer nemlig ikke, at vedkommende ikke behandler det ene individ dårligere end det andet. Hvis fx en hjælpeorganisation giver samme svinekødsbaserede suppe til såvel muslimske og jødiske som kristne hjemløse, så kan det meget vel være rigtigt, at den behandler muslimer og jøder værre end kristne, selvom der er en beskrivelse, under hvilken den behandler kristne, jøder og muslimer på samme måde. ${ }^{5,6}$ Hvilke beskrivelser, der er relevante for, om forskellige individer er blevet forskelsbehandlet, er naturligvis i sidste ende et spørgsmål om, hvilke beskrivelser der er relevante, og dermed et spørgsmål, der viser tilbage til, hvilke værdier og normer der er korrekte.

Den anden præcisering angår det forhold, at man kan behandle nogen dårligere end andre, uden at de nødvendigvis bliver stillet dårligere end andre som følge heraf. Der er med andre ord ingen nødvendig sammenhæng mellem 
kvaliteten af den behandling, man udsættes for, og kvaliteten af det udfald, man ender med at befinde sig i. Nazisterne behandlede jøder dårligere end andre, også de jøder, som flygtede til USA, og som endte med at være bedre stillede, end de ville have været, hvis de var forblevet i Europa (selv uden Holocaust).

Med disse to præciseringer i baghovedet kan vi give følgende basale karakteristik af diskrimination:

$\mathrm{X}$ diskriminerer mod $\mathrm{Y}$ i relation til $\mathrm{Z}$ ved at gøre $\varphi$, hvis, og kun hvis, (i) der er en egenskab, $\mathrm{P}$, således $\mathrm{Y}$ har $\mathrm{P}, \mathrm{og} \mathrm{Z}$ ikke har $\mathrm{P}$, (ii) $\mathrm{X}$ behandler $\mathrm{Y}$ værre end $\mathrm{Z}$ ved at gøre $\varphi, o g$ (iii) det er, fordi $\mathrm{Y}$ har $\mathrm{P}$, at $\mathrm{X}$ behandler $\mathrm{Y}$ værre end $\mathrm{Z}$ ved at gøre $\varphi$ (Narveson, 2002: 205).

Hvor X kan henvise til personer, men også til overindividuelle størrelser som fx grupper af individer, praksisser, institutioner og strukturer.

Det følger af den basale karakteristik, at diskrimination essentielt er et spørgsmål om forskelsbehandling. Det er ikke muligt at diskriminere mod nogen, uden at der er andre, som man behandler (eller eventuelt ville behandle) bedre. Herved adskiller diskrimination sig fra andre moralsk suspekte handlinger. Man kan ikke modgå en anke om, at man undertrykker en bestemt gruppe ved at pege på, at man ikke behandler dem anderledes end andre. Man kan derimod modgå en anke om diskrimination mod en bestemt gruppe ved at pege på, at man behandler den mindst lige så godt som andre grupper.

Af den basale karakteristik følger ikke, logisk set, at de, som diskrimineres mod, behandles på en i en ikke-komparativ forstand dårlig måde. Det følger heller ikke, at de, som udsættes for diskriminationen, bliver stillet ringere, end de ellers ville have været. Hvis vi fx forestiller os en fond, der favoriserer mandlige, hvide ansøgere, men altså fra tid til anden også støtter andre end sådanne, så kan ikke-(mandlige, hvide) ansøgere have ret i, at de bliver udsat for diskrimination, selvom de hverken bliver udsat for nogen i absolut forstand dårlig behandling eller bliver værre stillet, end hvis fonden slet ikke havde eksisteret, eller end hvis fonden havde eksisteret og fordelt sine midler uden en bias til fordel for mandlige, hvide ansøgere (fx fordi den så ville have haft meget færre midler til rådighed). Dette er foreneligt med, at typiske tilfælde af diskrimination involverer både dårlig behandling i en ikke-komparativ forstand, og at de, som udsættes for diskrimination, stilles værre end ellers.

Så vidt den basale karakteristik af diskrimination. Den indfanger utvivlsomt en nødvendig betingelse for, at noget udgør diskrimination. Men der skal føjes nogle yderligere betingelser til, førend vi har en tilstrækkelig betingelse for diskrimination. Antag at Anne, der er politibetjent, er tilkaldt til et gerningssted og der anholder Bent snarere end Claus, fordi Bent har en kniv i hånden 
og blod på tøjet. Annes behandling af Bent opfylder umiddelbart alle tre betingelser i den basale karakteristik af diskrimination: (i) Bent er bevæbnet og har blodigt tøj, det har Claus ikke; (ii) Anne behandler Bent værre end Claus ingen af dem har lyst til at blive anholdt; (iii) og det er, fordi Bent er bevæbnet og har blodigt tøj, at Anne anholder ham og ikke Claus. Når vi modsætter os diskrimination, så modsætter vi os ikke forskelsbehandling af den type, som Anne her udsætter Bent for. Ikke alle former for forskelsbehandling udgør diskrimination. Spørgsmålet er, hvilke former der gør. En måde, vi kan supplere den basale karakteristik på, er ved at tilføje følgende betingelse til den basale karakteristik:

(iv) det forhold, at $\mathrm{Y}$ har $\mathrm{P}$, og at $\mathrm{Z}$ ikke har, er irrelevant for, hvorvidt $\mathrm{X}$ bør gøre $\varphi$.

Ofte tænker vi netop på diskrimination som forskelsbehandling ud fra irrelevante hensyn, og det er da også klart, at Anne ikke diskriminerer mod Bent ud fra nærværende definition, da det forhold, at der er oplagte indicier på, at Bent er gerningsmanden, udgør en relevant grund til at anholde ham. Det var en anden sag, hvis Bent $\mathrm{fx}$ var blevet anholdt alene på grund af sin hudfarve. Spørgsmålet er imidlertid, om det er rimeligt at forstå diskrimination som forskelsbehandling ud fra irrelevante hensyn. Det er nemlig ikke alle sådanne former for forskelsbehandling, der almindeligvis anses for diskrimination. Tag fx forskelsbehandling af nepotistisk art. Hvis en rektor ansætter et familiemedlem som universitetsdirektør frem for en langt bedre kvalificeret ansøger, så vil vi ikke beskrive dette som diskrimination af ikke-familiemedlemmer, selvom vi er helt på det rene med, at der er tale om forskelsbehandling ud fra irrelevante hensyn (se fx „discrimination or nepotism“-passagen i Barry, 2005: 22).

Et yderligere problem er, at der er tilfælde af forskelsbehandling ud fra relevante hensyn, vi klassificerer som tilfælde af diskrimination. Tag tilfælde, der involverer forskelsbehandling ud fra såkaldte reaktionskvalifikationer, dvs. kvalifikationer, som en ansat har i kraft af den måde, hvorpå andre reagerer på vedkommende (Wertheimer, 1983: 99-112). ${ }^{7}$ Det at være charmerende udgør en oplagt reaktionskvalifikation i jobs, der involverer kundekontakt, og i et racistisk samfund kan det at have en bestemt race være en reaktionskvalifikation. Antag at en ikke-racistisk butiksindehaver i en af 50'ernes amerikanske sydstater ansætter en hvid ansøger frem for en sort alene ud fra den korrekte antagelse, at hvis han ansætter en sort ansøger, så er der mange kunder, der ikke vil handle i hans butik, hvorfor hudfarve økonomisk set er en relevant egenskab. Givet en forholdsvis alment accepteret antagelse om, at hensynet til indtjening er et relevant hensyn for en butiksindehaver, så vil en sådan forskelsbehandling ikke umiddelbart udgøre diskrimination ifølge den nærvæ- 
rende definition. Vi må derfor revidere definitionen, hvis vi vil fastholde, at butiksejerens forskelsbehandling udgør diskrimination. ${ }^{8}$ En måde at gøre det på er ved at erstatte (iv) med følgende betingelse:

(iv') det er moralsk forkert, at $\mathrm{X}$ behandler $\mathrm{Y}$ værre end $\mathrm{Z}$ ved at gøre $\varphi$, fordi $\mathrm{X}$ har P.

Ifølge den opfattelse, der kommer til udtryk her, så er diskrimination moralsk forkert forskelsbehandling. Det gør os i stand til at tage højde for sydstatseksemplet: Vi kan medgive, at hudfarve i dette tilfælde er en økonomisk set relevant kvalifikation, men tilføje, at eftersom det er moralsk forkert at forskelsbehandle folk på grund af deres hudfarve, så er der ikke desto mindre tale om diskriminerende forskelsbehandling.

Det er som allerede nævnt således, at når nogen kalder noget for diskrimination, så vil de ofte dermed tilkendegive, at de anser det for at være uretfærdigt eller moralsk forkert. Spørgsmålet er imidlertid, om det er formålstjenligt at indskrive dette i selve definitionen af diskrimination. Et problem er, at vi i så fald ikke kan sige, at noget er uretfærdigt eller umoralsk, fordi det udgør diskrimination, idet der så allerede i det, at noget udgør diskrimination, ligger, at det er uretfærdigt eller moralsk forkert.

Et andet problem er, at der er tilfælde, hvor en uenighed mellem to parter bedst beskrives som, at de er uenige, ikke om hvorvidt en bestemt form for forskelsbehandling udgør diskrimination, men derimod om hvorvidt en bestemt form for diskriminerende forskelsbehandling er uretfærdig eller forkert. Det gælder fx uenigheden om, hvorvidt sygehusvæsnet bør prioritere knappe resurser på en måde, der indebærer en negativ forskelsbehandling af ældre patienter.

For det tredje er det ikke givet, at den foreslåede revision i alle tilfælde giver os mulighed for at sige, at $\mathrm{fx}$ butiksindehaveren diskriminerer ved at forskelsbehandle sorte og hvide ansøgere, idet det ikke i alle tilfælde vil være klart, at butiksindehaveren handler moralsk forkert ved at forskelsbehandle. Antag fx at han vil gå konkurs måneden efter, hvis han undlader at forskelsbehandle; at han dermed bliver ude af stand til at betale lægeregninger for sine alvorligt syge børn; at de ansatte sorte butiksassistenter vil blive fyret umiddelbart efter deres ansættelse og forventeligt udsættes for chikane og vold fra Ku Klux Klantilhængeres side. Den foreslåede revision af diskriminationsdefinitionen tilfredsstiller med andre ord ikke det hensyn, der ligger bag ønsket om en revision heraf.

Et sidste problem er, at diskrimination i nærværende forstand stadig er et alt for bredt begreb. Jf. ovennævnte eksempel med nepotistisk ansættelse af et familiemedlem, så er det ikke enhver form for moralsk kritisabel forskelsbehandling, 
der udgør diskrimination. Det kunne motivere et tredje forslag til en ekstra betingelse, som tager sit udgangspunkt $i$, at næsten alle de former for diskrimination, der bliver anset for at være moralsk problematiske, vender sig mod grupper af individer, hvor disse grupper er socialt fremtrædende, fx sorte, homoseksuelle, muslimer osv. Med denne observation som ledetråd kunne man foreslå:

(iv") $\mathrm{P}$ er den egenskab at være et medlem af en bestemt socialt fremtrædende grupper (som $\mathrm{Z}$ ikke tilhører).

(iv") indfanger et væsentligt aspekt, men er ikke desto mindre ikke helt tilfredsstillende. Flere har indvendt mod noget i stil med ovenstående definition, at den indebærer, at en heteroseksuel person, som afviser en flirt fra en person, der har samme køn som vedkommende selv, diskriminerer - vedkommende afviser jo flirten „bare“ pga. den anden persons køn - men at en sådan forskelsbehandling åbenlyst ikke udgør et tilfælde af diskrimination (Cavanagh, 2002: 164). For at tage højde for den indvending kan vi supplere vores definition med følgende ekstra betingelse:

(v) $\varphi$ er en type af handlinger, der ofte forekommer, og det forhold stiller folk, der har $\mathrm{P}$, ringere end andre.

(v) gør os i stand til at tage højde for modeksemplet: homoseksuelle stilles ikke generelt ringere, fordi heteroseksuelle afviser flirter med dem. Til gengæld render vi ind i et lidt andet problem. For vores definition synes nu at være lidt for restriktiv. Antag at vi lever i et samfund domineret af protestanter, der ofte diskriminerer mod katolikker, og at en enlig katolsk arbejdsgiver systematisk afviser protestantiske ansøgere pga. enten et intenst had til protestanter eller en opfattelse af, at protestanter er mindreværdige, eller at protestanter og katolikker, om end ligeværdige, bør leve separate liv. Givet der er tale om et isoleret tilfælde af forskelsbehandling motiveret enten af fjendskab eller af en opfattelse af en anden gruppes underlegne status, er det ikke en form for forskelsbehandling, der udgør et samfundsmæssigt problem. Omvendt ligger det ikke i vores begreb om diskrimination, at der ikke kan forekomme enkeltstående tilfælde af diskrimination - at fx hvide i et samfund, hvori de udgør det bedst stillede og dominerende flertal, ikke i særlige kontekster kan udsættes for racediskrimination af sorte (jf. Blum, 2002: 8-11). Vi må derfor gøre vores definition bredere ved at indføje følgende disjunktive betingelse:

(vi) $\varphi$ er motiveret af fjendtlighed over for individer med $\mathrm{P}$ eller af den opfattelse, at individer med $\mathrm{P}$ har en lavere status end andre, eller at de bør holdes adskilt fra andre. 
Når vi tilføjer denne disjunktion til vores øvrige betingelser, indebærer vores definition, i lighed med den basale karakteristik, at diskrimination mod nogen nødvendigvis involverer, at man behandler dem værre end andre, men ikke nødvendigvis involverer, at de ender med at være værre stillede end andre som følge heraf. Vi har nu følgende definition af diskrimination:

Definition: $\mathrm{X}$ diskriminerer mod $\mathrm{Y}$ i relation til $\mathrm{Z}$ ved at gøre $\varphi$, hvis, og kun hvis, (i) der er en egenskab, $\mathrm{P}$, således $\mathrm{Y}$ har $\mathrm{P}$, og $\mathrm{Z}$ ikke har $\mathrm{P}$, (ii) X behandler Y værre end $\mathrm{Z}$ ved at gøre $\varphi$, (iii) det er, fordi $\mathrm{Y}$ har $\mathrm{P}$, at $\mathrm{X}$ behandler $\mathrm{Y}$ værre end $\mathrm{Z}$ ved at gøre $\varphi$, (iv") $\mathrm{P}$ er den egenskab at være et medlem af en bestemt socialt fremtrædende gruppe (som $Z$ ikke tilhører), og (v) $\varphi$ er en type af handlinger, der ofte forekommer, og det forhold stiller folk, der har P, ringere end andre, eller (vi) $\varphi$ er motiveret af fjendtlighed over for individer med P eller af den opfattelse, at individer med $\mathrm{P}$ har en lavere status end andre, eller at de bør holdes adskilt fra andre.

Denne definition forklarer, hvorfor ikke alle former for forskelsbehandling udgør diskrimination. Den indfanger næsten alle de former for forskelsbehandling, som folk har modsat sig under betegnelsen diskrimination (med såkaldt genetisk diskrimination i forbindelse med brug af genetisk information i forbindelse med fx beregning af præmier på livs- og sygeforsikringer som en undtagelse). Definitionen kan forfines yderligere, hvilket jeg har gjort andetsteds (Lippert-Rasmussen, 2007a). Her vil jeg rejse fire andre spørgsmål.

For det første vil læseren hæfte sig ved, at det ikke følger, logisk set, af ovenstående definition, at diskrimination er moralsk forkert eller uretfærdig. ${ }^{9}$ Det betyder selvfølgelig ikke, at man ikke kan mene, at alle former for diskrimination faktisk er uretfærdige og moralsk forkerte. Men det betyder, at man ikke modsiger sig selv, hvis man hævder, at noget udgør diskrimination, men ikke desto mindre hverken er moralsk forkert eller uretfærdigt. Nogle vil måske foretrække, at diskriminationsbegrebet netop er definitorisk set moralsk ladet og vil derfor foretrække at supplere min definition af diskrimination med en yderligere betingelse, som siger, at det er moralsk forkert eller uretfærdigt at gøre $\varphi$. Problemet her er blot, at hvis vi tilføjer en betingelse om, at der er tale om forskelsbehandling, som er moralsk forkert, alt taget i betragtning, så vil vi formentlig sagtens kunne forestille os diskriminerende former for forskelsbehandling, der er moralsk acceptable, alt taget i betragtning. Måske det fx er moralsk acceptabelt at tillade religiøse grupper at diskriminere mod personer, der ikke tilhører deres religion, hvis alternativet er en ødelæggende religiøst motiveret borgerkrig. Hvis omvendt vi tilføjer en betingelse om, at der er tale om forskelsbehandling, der er uretfærdig men ikke nødvendigvis moralsk forkert alt taget i betragtning, så vil man ikke opnå det, som en sådan ekstra klausul gerne skulle bevirke ifølge dens fortalere. Fx vil meritokrater 
med god ret kunne anse positiv særbehandling for en form for diskrimination, som godt nok er uretfærdig men også moralsk acceptabel alt taget i betragtning. Men mange, der foretrækker en moralsk non-neutral definition af diskrimination, vil netop være motiveret af et ønske om at skelne fx mellem den form for diskriminerende forskelsbehandling, der ligger i racistisk begrundet udelukkelse af bestemte grupper fra højere uddannelser, fra den form for ikkediskriminerende forskelsbehandling, der ligger i positiv særbehandling, som sigter mod at modvirke underrepræsentationen af bestemte racemæssigt definerede gruppers repræsentation (se fx Nickels, 1995: 3-4).

Det næste spørgsmål knytter sig til behovet for at præcisere begrebet om socialt fremtrædende grupper. Ikke alle grupper af individer er socialt fremtrædende. Gruppen af danskere, der har bopæl i et postdistrikt, hvis postnummer har en tværsum på fire, er en gruppe, medlemskab af hvilken er klart defineret. Men gruppen er ikke socialt fremtrædende. Der er ingen kontekster for social interaktion, hvor det medvirker til at strukturere den sociale interaktion, hvilken tværsum aktørernes postnumre har. Derved adskiller gruppen sig fra gruppen af mænd, andengenerationsindvandrere og bistandsklienter. Spørgsmålet om, hvorvidt en gruppe er socialt fremtrædende, er reelt et gradsspørgsmål, og det er derfor i nogen grad arbitrært, om en gruppe er tilstrækkeligt socialt fremtrædende til, at negativ forskelsbehandling af gruppen udgør diskrimination mod den. Det er også klart, at der kan ligge en social kamp $i$ at opnå almen anerkendelse af, at medlemskab af en bestemt gruppe har en stor strukturerende indflydelse på social interaktion i mange kontekster, og at gruppen derfor kandiderer til en gruppe, der er udsat for diskrimination. Jf. eksemplet i det indledende afsnit så vil nogle fx hævde, at rygere i dag er udsat for systematisk forskelsbehandling i en lang række kontekster, således at den forskelsbehandling, de udsættes for, kan paralleliseres til andre former for diskrimination (jf. Dummett, 2004: 27-34).

For det tredje fordrer foreslåede definition en forklaring af, hvad der ligger $\mathrm{i}$, at det er, fordi $\mathrm{Y}$ tilhører en bestemt socialt fremtrædende gruppe, at $\mathrm{X}$ gør $\varphi$ (og dermed behandler Y værre end Z). En mulighed er følgende:

(a) $\mathrm{X}$ behandler $\mathrm{Y}$ værre end $\mathrm{Z}$ ved at gøre $\varphi$, fordi $\mathrm{Y}$ har $\mathrm{P}$ hvis, og kun hvis den opfattelse, at Y har P, er en del af X's motiverende grund til at gøre $\varphi$.

(a) passer fint på en række paradigmatiske tilfælde af diskrimination, jf. fx den hadefulde racist, der nægter at ansætte en person, alene fordi vedkommende er sort. Ikke desto mindre lægger (a) op til en snæver forståelse af diskrimination, der indskrænker diskrimination til såkaldt „,direkte diskrimination“. Imidlertid er det i dag almindeligt anerkendt, at et mindst lige så vigtigt diskriminationsfænomen er indirekte diskrimination, dvs. det forhold at regler, insti- 
tutioner og praksisser har ulige effekter på forskellige socialt fremtrædende grupper, ikke fordi, eller i det mindste langt fra udelukkende fordi, personerne, der følger de relevante regler, bemander de pågældende institutioner eller er involverede i nævnte praksisser, er negativt indstillede over for de grupper, som stilles ringere. For at tage et eksempel fra en amerikansk kontekst: En større virksomhed forfremmer og har altid forfremmet personer til lederstillinger efter et anciennitetsprincip (se Ezorsky, 1991: 24-26). Anciennitetsprincippet er ikke motiveret af nogen form for bias mod afroamerikanere. Imidlertid er det således, at virksomheden tidligere har foretrukket ikke at ansætte afroamerikanere, hvorfor der er uforholdsmæssigt mange hvide ansatte i virksomheden. I praksis vil anciennitetsprincippet dermed medføre, at en uforholdsmæssig stor del af lederne i virksomheden i en rum tid fremover vil være hvide. En sådan virksomhed kunne, i det mindste i 70'ernes USA, meget vel blive dømt for indirekte diskrimination, selvom domstolene anerkender, at anciennitetsprincippet ikke på nogen måde er racistisk motiveret. Det afgørende her er, at forfremmelsesproceduren stiller gruppen af afroamerikanere ringere end andre. For at gøre plads til indirekte diskrimination er vi derfor nødt til at udvide vores forståelse af, hvad der ligger i, at nogen behandles dårligere pga. deres medlemskab af en bestemt socialt fremtrædende gruppe:

(b) X behandler $Y$ værre end $Z$ ved at gøre $\varphi$, fordi $Y$ har P, hvis, og kun hvis, det faktum, at $\mathrm{Y}$ har $\mathrm{P}$, kausalt forklarer $\varphi$.

(b) tager højde for indirekte diskrimination. For så vidt angår vores eksempel kunne man sige, at det forhold, at en given generation af arbejdere er afroamerikanere, forklarer, hvorfor de er dårligere repræsenteret på lavere niveauer i virksomheden, og at det sammen med anciennitetsreglen forklarer, hvorfor de er dårligere repræsenteret på ledelsesniveau. Problemet med (b) er, at opfattelsen indebærer en alt for bred forståelse af diskriminationsfænomenet. Det kan synes rimeligt at antage, at i næsten alle tilfælde hvor regler, institutioner og praksisser genererer bedre resultater for nogle socialt fremtrædende grupper, så vil dette i det mindste delvist kunne forklares gennem gruppetilhørsforhold. Hvis fx subkulturelle og majoritetsnormer, -regler, -praksisser osv. genererer en overrepræsentation af kvinder og pakistanske indvandrere på videregående studier, og at mænd og personer med ikke-pakistansk baggrund derfor er underrepræsenterede, så vil vi ikke deraf slutte, at mænd og personer med ikke-pakistansk baggrund er udsat for indirekte diskrimination (Lippert-Rasmussen, under udgivelse). Problemet her er, at de relevante regler, institutioner og praksisser, der genererer differentielle effekter for kvinder og mænd, personer med pakistansk baggrund og personer uden, ikke genererer dårligere resultater for grupper, der i nogen væsentlig grad har været udsat 
for direkte diskrimination. Det synes med andre ord at være en betingelse for, at vi vil tale om indirekte diskrimination mod en gruppe, at den faktisk også er eller har været udsat for direkte diskrimination (jf. Garcia, 2001: 284). Det lægger op til følgende skærpelse af (b):

(c) $\mathrm{X}$ behandler $\mathrm{Y}$ værre end $\mathrm{Z}$ ved at gøre $\varphi$, fordi $\mathrm{Y}$ har $\mathrm{P}$, hvis, og kun hvis, (1) det faktum, at $\mathrm{Y}$ har $\mathrm{P}$, kausalt forklarer $\varphi, \mathrm{og}(2)$ at personer typisk er eller typisk har været udsat for forskelsbehandling, hvor en del af den motiverende grund til forskelsbehandling er det forhold, at Y har P.

(c) har imidlertid en interessant implikation for så vidt angår indkomst - en implikation, der foranlediger det fjerde annoncerede spørgsmål i tilknytning til min diskriminationsdefinition - og som umiddelbart er et problem for (c). En lang række regler, institutioner og praksisser er indrettet på en sådan måde, at de systematisk genererer bedre resultater for højindkomstgrupper. Tag $\mathrm{fx}$ det forhold, at børn typisk går i en skole, der ikke ligger langt fra forældrenes bopæl. Sammen med boligmarkedets måde at fungere på betyder det, at børn af forældre med høj indkomst typisk vil gå på en skole med andre børn af forældre med høj indkomst, og at det typisk vil betyde, at de får en bedre (folke)skolegang end børn med lavindkomstforældre. (c) lægger op til, at dette meget vel kan udgøre indirekte indkomstdiskrimination, forudsat naturligvis at lavindkomstgrupper udsættes for forskelsbehandling på grund af deres gruppetilhørsforhold. Det forekommer imidlertid vanskeligt at benægte, at en sådan forskelsbehandling forekommer. En grund hertil er, at statussymboler spiller en så stor rolle, som tilfældet er. Ideen bag statussymboler er, at man igennem disse signalerer ens status, herunder ens høje indkomst, og derigennem bliver behandlet bedre, end man ellers ville være blevet. Hvis vi lægger (c) til grund for vores forståelse af diskrimination, følger det derfor, at en meget vigtig form for diskrimination er indkomstdiskrimination. Imidlertid er det sådan, at mens de fleste anerkender, at der kan forekomme racediskrimination, kønsdiskrimination, diskrimination mod handicappede osv., så er det meget ualmindeligt at tale om indkomstdiskrimination.

Min opfattelse her er, at dette er et skinproblem. Givet hvad vi i øvrigt mener, så burde mange af os være meget mere optaget af indkomstdiskrimination, end tilfældet er. Endvidere er der flere forklaringer på, hvorfor vi er mindre opmærksomme på indkomstdiskrimination, der er forenelige med, at der faktisk forekommer indkomstdiskrimination. For det første er ens indkomst mindre synlig end fx ens køn eller race. For det andet overvurderer folk typisk den grad, i hvilken ens indkomst kan variere over tid. Derimod er det de færreste, som forestiller sig, at selvom de lige nu er sorte eller kvinder, så kan de meget vel være hvide eller mænd ti år senere. For det tredje er indkomst 
gradueret, mens typiske diskriminationsgrupper lidt forsimplet hviler på dikotomiske sondringer: mand/kvinde, hvid/ikke-hvid, handicappet/ikke-handicappet. Det gør det langt mere vanskeligt at identificere og mobilisere de personer, der er udsat for indkomstdiskrimination. For det fjerde er de problemer, som grupper, der er udsat for indkomstdiskrimination, typisk og primært oplever, ikke diskriminationsspecifikke problemer som stigmatisering, men derimod simpelthen det forhold, at der er en række goder, de er afskåret fra grundet lav indkomst. Endelig fremføres kravet om at eliminere eller reducere diskrimination som oftest som et krav, der kan imødekommes ved relativt begrænsede reformer af det eksisterende samfund. Et krav om at eliminere indkomstdiskrimination synes derimod at forudsætte meget vidtgående egalitaristiske samfundsforandringer.

\section{Hvorfor er diskrimination forkert?}

Indtil nu har jeg været optaget af at definere diskrimination. I artiklens sidste del vil jeg med afsæt i ovenstående bestemmelse diskutere, hvorfor diskrimination er moralsk forkert. Til det formål bør jeg starte med at skelne mellem to måder at forstå spørgsmålet på.

Den første måde at forstå spørgsmålet på indebærer, at det, vi spørger til, er hvilke, om nogen, af de egenskaber, som pr. definition kendetegner diskrimination, der gør diskrimination moralsk forkert. For at besvare det spørgsmål skal vi se bort fra alle de egenskaber, der typisk, men ikke med nødvendighed, knytter sig til diskrimination. Hvis fx det typisk er sådan, at personer bliver stillet ringere end andre, når de bliver udsat for diskrimination, men at det, som tilfældet er, ikke indgår i selve definitionen af diskrimination, at den, som diskrimineres mod, bliver stillet ringere end andre, så skal vi se bort fra dette forhold og spørge til, om der er noget moralsk forkert ved diskrimination i fraværet af, at den, som diskrimineres mod, bliver stillet ringere som følge heraf. Vi skal med andre ord fokusere alene på den definition af diskrimination, som vi fremstillede i artiklens første del, og spørge til, om der er nogle af de elementer, som indgår i denne definition, i kraft af hvilke eller i kraft af kombinationer af hvilke, diskrimination er moralsk forkert. Vi spørger til, om diskrimination i sig selv er moralsk forkert.

Den anden og mere løse måde at forstå spørgsmålet på tager udgangspunkt i en, i mine øjne rimelig, antagelse om, at de fleste af de diskriminationsfænomener, som vi er optagede af, er moralsk forkerte, og at det, vi spørger til, er, hvilke egenskaber ved disse diskriminationsfænomener der gør dem moralsk forkerte. Relevante svar på dette spørgsmål begrænser sig ikke til definitoriske egenskaber ved diskrimination. Vi kan hævde, at det, som gør diskrimination moralsk forkert, er, at det stiller dem, som udsættes for diskrimination, værre end andre, og samtidig medgive, at dette på ingen måde er en 
begrebsligt set nødvendig egenskab ved diskrimination - blot er det således, det faktisk forholder sig - når vi forstår spørgsmålet på den anden måde. Vi kan med andre ord hævde, at de fleste (eller måske alle) tilfælde af diskrimination er moralsk forkerte, blot er de ikke forkerte, fordi de udgør tilfælde af diskrimination, men af andre grunde. Lad os med sondringen mellem disse to måder at forstå vores spørgsmål på i baghovedet prøve at se på nogle typiske svar på, hvorfor diskrimination er moralsk forkert (fremstillingen i resten af afsnittet trækker på Lippert-Rasmussen, 2007b).

Mange tilslutter sig den meritokratiske opfattelse, at diskrimination er moralsk forkert, fordi diskrimination forhindrer, at attraktive positioner i samfundet tilfalder de bedst kvalificerede ansøgere (Miller, 1992: 161-181). Lige så almindelig denne opfattelse er, lige så klart er det også, at den i bedste fald alene forklarer, hvorfor diskrimination i ansættelsessammenhænge er moralsk forkert. Der forekommer imidlertid diskrimination i mange andre sammenhænge, jf. fx kønsdiskrimination i opdragelsen. Selv hvis vi indskrænker os til ansættelsessammenhænge, så er det tvivlsomt, om en meritokratisk forklaring af, hvad der er galt med diskrimination, er tilfredsstillende. For det forste er det ikke givet, at det meritokratiske princip har selvstændig, snarere end en afledt, moralsk relevans, der hidrører fra de moralsk relevante hensyn, der typisk varetages bedst, hvis vi efterlever det meritokratiske princip, fx hensynet til den almindelige velfærd. For det andet så er det tvivlsomt, om det moralske problem, der ligger i en diskriminerende ansættelsespolitik, alene kan reduceres til en krænkelse af et meritokratisk princip. Antag at en arbejdsgiver ansætter en person, der er klart dårligere kvalificeret end en anden ansøger, fordi førstnævnte virkede mere sympatisk ved jobsamtalen. Det er uplausibelt, at denne arbejdsgiver handler forkert af præcis samme grund som en arbejdsgiver, der ikke ansætter en bedre kvalificeret sort, kvindelig ansøger til en lederstilling, fordi han ikke bryder sig om, at sorte kvinder giver ordrer til hvide mandlige underordnede. Men i så fald må diskrimination være moralsk forkert af grunde, der ikke indfanges af meritokratiprincippet, da der for så vidt angår meritokratiprincippet ikke er forskel mellem de to eksempler.

En anden udbredt opfattelse fokuserer på det forhold, at diskrimination indebærer mulighedsulighed. En oplagt begrundelse for at modsætte sig kønsdiskrimination er netop, at det er uretfærdigt, at mænd skal have bedre muligheder end kvinder blot på grund af deres køn. De fleste kan blive enige om, at mulighedsulighed er moralsk problematisk. Retfærdigheden kræver ikke, at alle ender med at have det lige godt. Men den forudsætter, at alles muligheder til at begynde med er de samme. Det er så op til hver enkelt at få det bedste ud af dem. En fordel ved denne forklaring er, at den - i modsætning til den meritokratiske - ikke blot er begrænset til ansættelsessammenhænge, men også kan forklare, fx hvorfor diskrimination i familien er forkert. Det er dog også klart, 
at selvom mange af de klassiske eksempler på diskrimination indebærer mulighedsulighed, så er der ingen nødvendig forbindelse mellem mulighedslighed og fravær af diskrimination (Cavanagh, 2002: 153-160). Vi kan, logisk set, have mulighedslighed og diskrimination, og vi kan have mulighedsulighed og ingen diskrimination. Diskrimination kan i visse situationer ligefrem være et middel til at sikre mulighedslighed! Når vi kan have mulighedslighed og diskrimination, skyldes det blandt andet, at diskriminationen så at sige kan virke til fordel for dem, som har de dårligste muligheder. Det sker måske sjældent, men det er irrelevant for, om vi helt generelt kan forklare, hvad der er dårligt ved diskrimination ved at henvise til idealet om mulighedslighed. Antag $\mathrm{fx}$, at medlemmerne af en bestemt indvandrergruppe investerer mange ressourcer i deres børns uddannelse og opmuntrer dem på alle mulige måder til at blive læger, ingeniører, advokater osv. Det kan meget vel være, at givet dette forhold så har en teenager fra den pågældende indvandrergruppe bedre muligheder end dels teenagere fra andre indvandrergrupper, dels teenagere fra ikke-indvandrergrupper. Noget sådant gælder faktisk visse asiatiske indvandrergrupper i USA. Diskrimination mod en sådan succesfuld indvandrergruppe kan være noget, der skaber større mulighedslighed, ikke mindre. Så hvis diskrimination er forkert, alene fordi det skaber mulighedsulighed, tvinges man til at sige i det konkrete tilfælde, at der her ikke er noget forkert i at diskriminere mod den pågxldende indvandrergruppe. Mange vil formentlig konkludere, at da diskrimination også i et sådant tilfælde vil være forkert, kan hensynet til mulighedslighed ikke alene forklare, hvorfor vi ikke bør diskriminere. Hvis vi derfor stiller vores spørgsmål: „Hvorfor er diskrimination moralsk forkert?" i den forste af de to betydninger, jeg har skelnet imellem, så kan hensynet til mulighedslighed ikke være svaret. Det indgår ikke i definitionen af diskrimination, at diskrimination øger mulighedsuligheden, og det er kun de definitoriske egenskaber, vi skal fokusere på ifølge den første opfattelse. Hvis vi derimod har den anden af de to betydninger i tankerne, så kan vi sige, at mange af de tilfælde af diskrimination, som vi kender, er moralsk forkerte, fordi de øger mulighedsuligheden. Det er i kraft af blandt andet dette typiske ikkedefinitoriske træk, at diskrimination hævdes at være moralsk problematisk.

Et tredje synspunkt, som naturligt byder sig til i kølvandet på mit eksempel med den ambitiøse indvandrergruppe, er, at diskrimination er forkert, fordi diskrimination involverer, at man er disrespektfuld over for den, som man diskriminerer mod. Hvis man $\mathrm{fx}$ afviser at ansætte et bedre kvalificeret medlem af den succesfulde indvandrergruppe, handler man jo stadigvæk disrespektfuldt over for vedkommende, selv hvis diskrimination mod denne gruppe sikrer mulighedslighed.

Respekt er et begreb, som historisk set har spillet en central rolle inden for kantiansk etik. Her er respekt primært knyttet til en bestemt holdning, som 
man bør anlægge over for andre fornuftsvæsner. Spørgsmålet er imidlertid, hvad præcist der ligger i at være disrespektfuld over for et offer for diskrimination. Et indflydelsesrigt svar er, at diskrimination involverer, at man behandler en person, som om vedkommende har en lavere moralsk status, end vedkommende faktisk har, og det er disrespektfuldt at gøre noget sådant (Alexander, 1992-3). Vi kan sagtens se, hvad der tænkes på her. Når fx en sort person under apartheid i Sydafrika bortvises fra en offentlig park, hvor det er ulovligt at opholde sig for alle andre end hvide, så bliver vedkommende behandlet som havende en lavere moralsk status, end vedkommende har. Vedkommende har nemlig samme moralske ret, ville vi sige, som hvide til $\mathrm{fx}$ at opholde sig i offentlige parker. Men når personen bortvises fra den offentlige park, behandles personen på en måde, som kun ville være moralsk acceptabel, hvis personen ikke havde samme moralske rettigheder som hvide.

Spørgsmålet er imidlertid, om alle former for diskrimination nødvendigvis involverer disrespekt i denne forstand. Fx strukturel diskrimination på arbejdsmarkedet til fordel for mænd synes ikke nødvendigvis at involvere disrespekt. ${ }^{10}$ Mænd kunne formentlig være helt på det rene med, at kvinder har præcis samme moralske status som mænd, men ikke desto mindre være med til at fastholde strukturer, der begunstiger dem i forhold til kvinder, simpelthen fordi det er i deres egeninteresse. Det forudsætter naturligvis, at man kan medvirke til, at nogen behandles på en måde, som de ikke bør blive behandlet på, uden at man dermed er disrespektfuld over for dem. Netop den antagelse vil nogle tilhængere af respekttilgangen angribe: Hvis man behandler nogen eller medvirker til, at nogen bliver behandlet dårligere, end de bør blive behandlet, så følger der heraf, at de bliver behandlet disrespektfuldt. Hvis man medgiver denne påstand, så vil strukturel diskrimination, modsat hvad jeg først antog, også involvere disrespekt. Problemet er blot, at vi med denne bevægelse har berøvet respekttilgangen dens evne til at løse den opgave, som var baggrunden for, at vi introducerede den. For den opgave, vi ønskede at bruge tilgangen til, var at forklare, hvad det er, som gør diskrimination moralsk forkert. Men med den meget brede forståelse af disrespekt, som vi nu har lagt til grund, siger vi ikke, at diskrimination er forkert, fordi det involverer disrespekt. I stedet siger vi, at der foreligger disrespekt, når nogen behandles forkert. Men hvis vi først må vide, hvorvidt en handling er moralsk forkert, førend vi kan afgøre, om den involverer disrespekt, så kan vi ikke samtidig hævde, at handlinger er moralsk forkerte, fordi de involverer disrespekt. Denne ubehagelige cirkularitet synes at tvinge os tilbage i en mere snæver forståelse af disrespekt, hvor vi formentlig må medgive, at mange former for diskrimination ikke nødvendigvis involverer nogen form for disrespekt. Disrespekt er derfor ikke svaret på vores spørgsmål under den første af vores to forståelser heraf, selvom visse direkte former for diskrimination involverer forskellige former for disrespekt. 
En fjerde og sidste forklaring på, hvorfor diskrimination er moralsk forkert, henviser til den skade, de, som udsættes for diskrimination, lider. Den forklaring indfanger noget centralt ved, hvorfor vi anser diskrimination som værende etisk set problematisk. Det er fx sjældent, at nogen protesterer over at være blevet udsat for diskrimination, samtidig med at de medgiver, at de (eller andre i deres situation) skam på ingen måde er blevet stillet ringere som følge af denne diskrimination. Det viser selvfølgelig ikke, at det eneste, som er galt med diskrimination, er, at det skader dem, som udsættes for det. Men det taler dog for, at det i det mindste er en vigtig del af billedet. Hvis vi skal udfolde skadestilgangen til diskrimination, må vi selvfølgelig sige lidt mere om, hvad der ligger $i$, at nogen skades i den relevante forstand. Det kan gøres på forskellige måder. Et hovedsynspunkt er, at man bliver skadet, hvis ens livskvalitet forringes. Der er forskellige opfattelser af, hvori livskvalitet består, $\mathrm{fx}$ at ens rationelle ønsker for ens eget liv bliver opfyldt (Parfit, 1986: appendix I). Et andet hovedsynspunkt er, at man bliver skadet, hvis man bliver stillet ringere $\mathrm{i}$ en eller anden henseende, som ikke nødvendigvis knytter sig til ens livskvalitet. For at se forskellen mellem disse to opfattelser kan man fx forestille sig, at en gruppe som følge af diskrimination har en lavere indtægt og et lavere uddannelsesniveau, end den ellers ville have haft, men at gruppens medlemmer ikke af den grund har en lavere livskvalitet, $\mathrm{fx}$ fordi det forhold, at gruppen er udsat for diskrimination, giver et stærkt gruppeinternt sammenhold og et deraf følgende blomstrende socialt liv. Formentlig vil de mest markante eksempler på diskrimination skade ofrene, uafhængigt af hvilken opfattelse af skade man lægger til grund. Uanset hvad så er det klart, at selvom diskrimination i næsten alle tilfælde skader dem, som udsættes for den, og at de eksempler, som vi umiddelbart vil tænke på som de mest slående eksempler på moralsk set uønskværdige tilfælde af diskrimination, alle har det til fælles, at de, som bliver udsat for diskrimination, skades, er der kun et kontingent forhold mellem diskrimination og skade. Som allerede anført så indgår det ikke i vores definition af diskrimination, at den, som bliver behandlet værre, bliver skadet herved: En usædvanlig person, der udsættes for en diskriminerende behandling, og som reagerer herpå ved at have større ambitioner, disciplin og motivation og som i sidste ende får gavn heraf, er ikke blevet skadet ved at blive diskrimineret. Hvis det moralsk problematiske i diskrimination således ligger i den skade, som de, der udsættes for den, påføres, så kan der være tilfælde af diskrimination, der ikke er moralsk uønskværdige (Lippert-Rasmussen, 2007b, 2006a).

\section{Konklusion}

Jeg har ovenfor defineret diskrimination og fremstillet fire forskellige synspunkter på, hvad der gør, at diskrimination er moralsk set problematisk. Ingen af disse synspunkter udelukker, at visse former for diskrimination er moralsk 
uproblematiske. Det betyder ikke, at velkendte former for race- og kønsdiskrimination pludselig slet ikke er moralsk kritisable. Men det betyder, at det er kompliceret at give en principiel forklaring på, hvorfor de er moralsk kritisable - måske forskellige former for diskrimination er moralsk forkerte af forskellige grunde? - og at vi måske gør bedst i at konkludere, at de egenskaber, som gør noget til diskrimination, ikke er de egenskaber ved typiske tilfælde af diskrimination, der gør disse moralsk forkerte. Alternativet er at hævde, at forskelsbehandling på grundlag af medlemskab af socialt fremtrædende grupper i sig selv er moralsk forkert, dvs. selv når en sådan forskelsbehandling på meget atypisk vis ikke medfører: at dårligere kvalificerede ansættes i attraktive stillinger, at mulighedsuligheden øges, at nogle personer behandles disrespektfuldt, eller at nogle person skades som folge af, at de udsættes for diskrimination. $^{11}$

\section{Noter}

1. Definitionen indfanger formentlig en nødvendig men også klart utilstrækkelig betingelse for, at en aktivitet er diskriminerende.

2. Rektor for Københavns Universitet besvarer således et debatindlæg, hvori en regel, der betyder, at studerende over 30 år ikke kan indlevere prisopgaver, kritiseres på følgende vis: „I overskriften af Mikkel Pedersbæks læserbrev står der 'aldersdiskrimination' ... Og det er jo rigtigt at der sættes en grænse der udelukker nogen. Men alle regler har til opgave at diskriminere, det er simpelthen reglers eksistensberettigelse“, Universitetsavisen 2.2.2007, p. 15.

3. „Man kan vel dårligt tænke sig, at et af de store dagblade ville bringe denne overskrift: 'Københavns Universitet støtter marginaliseringen og diskrimineringen af udsat gruppe'? Men måske ville det være berettiget i lyset af universitets rygeforbud pr. 1. september", kronik i Information 7.9.2006, p. 34 .

4. „Det Kongelige Teater bliver nu undersøgt for racediskrimination, fordi de giver flygtninge og indvandrere en klækkelig rabat for at lokke dem i teatret. Klagekomiteen for Etnisk Ligestilling vil lave en forundersøgelse af, om teatret bryder loven, når de lader folk fra ikke-vestlige lande, sætte sig i sæderne for 40 kroner under en tiendedel af normalprisen - til syv udvalgte forestillinger", Nybedsavisen 23.1.2007, p. 22.

5. For et interessant eksempel se http://news.bbc.co.uk/2/hi/europe/4644766.stm (åbnet 8.8.2007).

6. Se Karl Marx' kritik af retten til lighed i dennes kritik af Gothaprogrammet (1875: 15-32).

7. Jeg diskuterer Wertheimers syn i „The Heterogenity of the Ideal of Merotocracy“ (upubliceret).

8. Alternativt kunne man fastholde: at butiksindehaveren ikke diskriminerer; at sorte ansøgere udsættes for diskrimination; men at den, som udsætter dem for diskrimination, er en anden agent end butiksindehaveren, fx dennes kunder eller overindividuelle arbejdsmarkedsstrukturerer; og endelig at den pågældende diskriminatoriske kontekst er moralsk problematisk.

9. Ud fra den betragtning at andre overvejelser, end om noget er retfærdigt, har be- 
tydning for, om noget er moralsk rigtigt, er anken om, at noget er moralsk forkert, en anden og bredere anke, end anken om, at noget er moralsk uretfærdigt.

10. Noget tilsvarende gælder såkaldt statistisk diskrimination, hvor statistisk information om forskellige grupper danner grundlag for forskelsbehandling (se LippertRasmussen, 2007c).

11. En tak til Søren Flinch Midtgaard og Sune Lægaard for meget nyttige kommentarer til denne artikel.

\section{Litteratur}

Alexander, Larry (1992-3). „What Makes Wrongful Discrimination Wrong?“, University of Pennsylvania Law Review, Vol. 141, pp. 149-219.

Barry, Brian (2005). Why Social Justice Matters, Cambridge: Polity Press.

Blum, Lawrence (2002). I'm Not a Racist, but ..., Ithaca: Cornell University Press.

Cavanagh, Matt (2002). Against Equality of Opportunity, Oxford: Clarendon Press).

Dummett, Michael (2004). „The Nature of Racism“, pp. 27-34 in Michael P. Levine and Tamas Pataki (eds.), Racism in Mind, Ithaca: Cornell University Press.

Ezorsky, Gertrude (1991). Racism and Justice: The Case for Affirmative Action, Ithaca: Cornell University Press.

Garcia, Jorge L.A. (2001). „The Heart of Racism“, pp. 256-296 in Bernard Boxill (ed.), Race and Racism, Oxford: Oxford University Press.

Giddens, Anthony (1997). Sociology, London: Polity Press.

Lippert-Rasmussen, Kasper (2006a). „The Badness of Discrimination“, Ethical and Moral Practice, Vol. 9, No. 2, pp. 167-185.

Lippert-Rasmussen, Kasper (2006b). „Private Discrimination: A Prioritarian, DesertAccommodating Account“, San Diego Law Review, Vol. 43, pp. 817-856.

Lippert-Rasmussen, Kasper (2007a). „Discrimination“, in Thomas Petersen et al. (eds.), New Waves in Philosophy: Applied Ethics, Basingstoke: MacMillan Palgrave.

Lippert-Rasmussen, Kasper (2007b). „Hvad er diskrimination?“, kapitel 2 i Kasper Lippert-Rasmussen og Jesper Ryberg (red.), Født og Forbliver Lige og Frie?, København: Museum Tusculanum Press.

Lippert-Rasmussen, Kasper (2007c). „Nothing Personal: On Statistical Discrimination“, Fournal of Political Philosophy, Blackwell Synergy.

Lippert-Rasmussen, Kasper (under udgivelse). „Discrimination and the Aim of Proportional Representation", Politics, Philosophy, and Economics.

Marx, Karl (1875). „Kritik af Gothaprogrammet“, $M E W$, bd. 19, Berlin: Dietz Verlag. Miller, David (1992). „Deserving Jobs“, Philosophical Quarterly, Vol. 42, pp. 161-181.

Narveson, Jan (2002). „Have We a Right to Non-Discrimination?“, pp. 203-224 in Jan Narveson, Respecting Persons in Theory and Practice: Essays on Moral and Political Philosophy, New York: Rowman and Littlefield Publishers, Inc.

Nickels, James W. (1995). „Discrimination and Morally Relevant Characteristics“, in Stephen M. Cahn (ed.), The Affirmative Action Debate, London: Routledge.

Parfit, Derek (1986). Reasons and Persons, Oxford: Oxford University Press.

Wertheimer, Alan (1983). „Jobs, Qualifications, and Preferences“, Ethics, Vol. 94, pp. 99-112. 